\title{
【シンポジウム 12】
}

\section{競技力向上とスポーツ医・科学サポート \\ 〜ジュニアからトップアスリートへの道}

\author{
清 水 茂 幸
}

(岩手大学)

スポーツにおける競技力の向上にはスポーツ医・科学 サポートが重要な役割を担っている。それはトップアス リートに限ったことではなく, ジュニアアスリートに とっても同様である。早期に優れた素質を持つジュニア アスリートを発掘し, 系統的に能力開発をしょうとする タレント発掘・育成事業は地方公共団体や競技団体など で行われているが, その基本となるのはスポーツ医・科 学サポートである。

このシンポジウムではスポーツ医学, スポーツ歯学, スポーツ科学, スポーツ栄養の各分野の経験豊富な先生 方からお話をいただき，それをもとにジュニアからトッ プアスリートに関わる指導上のポイントや課題などにつ いて討論を展開した。

まずシンポジウムに先立って, 清水が発育発達の観点 からジュニアアスリートの育成に関する総論を述べた。 主な内容は, (1)小, 中学校期は無理なトレーニングを絶 対に行わない. (2)小学校期は脳神経系を, 中学校期は呼 吸循環器系を, 高校期は筋力系を含んだ体力全体の底上 げを中心にトレーニングすべきである。(3)アスリートの 花咲く時期はいつ訪れるかわからない, といったことで ある。

続いて, 向井直樹氏からスポーツ医学的見地から知見 を述べていただいた。「努力は必ず報われる」というの は必ずしも医学的見地からは正しくない. そのようにア スリートに信じ込ませ過度なトレーニングをさせないよ う指導者に警鐘を与えていた。

近藤尚知氏からは，スポーツ歯学的見地から知見をい ただいた。特に，ジュニアアスリートは一般児童・生徒
に比べると齨歯率が高く, 注意が必要であること, また スポーツドリンクは必ずしも齲歯率を高めるわけではな いとの報告をいただいた。

鈴木省三氏からは，トレーニング学的見地から宮城県 のジュニアアスリート発掘育成事業の紹介と，特にそり 競技に取り組むための様々な方策をご報告いただいた。 現在全国各地でタレント発掘育成事業が進行中である が，本事例はそれらの事業の方向性に大いなる指針とな るものと思われる。

木村典代氏からは, スポーツ栄養学的見地から, ご自 身が関わられている卓球ナショナルチームの栄養指導の 具体的内容をご紹介いただくともに，ジュニアアスリー トの食生活に関してのサゼスチョンをいただいた。特に 印象的だったのは，「味音痴はトップアスリートを育てる」 という知見で，どんな環境においても，どんな食事内容 でも, 平気でしっかり食事を食べられることがジュニア 期のアスリートには大事であるという報告であった。

各氏からのご報告の後，総合討論を行った，時間の関 係で，十分な討論が行えなかったが，各氏からの報告の 補足等をいただき，会を閉じた。

今回の公開シンポジウムは, 県民公開講座としての企 画でもあり, 岩手県のスポーツ関係者, ジュニアアスリー 卜および保護者にも多数来場していただき，最新の知見 を紹介できたことに大いに意義があったと考える。今回 紹介された知見を是非今後のスポーツ活動に生かしてい ただければ幸いである。 